\title{
Chemotaxonomy of the genus Stemphylium
}

\author{
Olsen, Kresten Jon Kromphardt; Andersen, Birgitte
}

Publication date:

2016

Document Version

Publisher's PDF, also known as Version of record

Link back to DTU Orbit

Citation (APA):

Olsen, K. J. K., \& Andersen, B. (2016). Chemotaxonomy of the genus Stemphylium. Poster session presented at 9th Joint Natural Products Conference 2016, Copenhagen, Denmark.

\section{General rights}

Copyright and moral rights for the publications made accessible in the public portal are retained by the authors and/or other copyright owners and it is a condition of accessing publications that users recognise and abide by the legal requirements associated with these rights.

- Users may download and print one copy of any publication from the public portal for the purpose of private study or research.

- You may not further distribute the material or use it for any profit-making activity or commercial gain

- You may freely distribute the URL identifying the publication in the public portal

If you believe that this document breaches copyright please contact us providing details, and we will remove access to the work immediately and investigate your claim 


\title{
Chemotaxonomy of the genus Stemphylium
}

\author{
Kresten Jon Kromphardt Olsen and Birgitte Andersen
}

Department of Biotechnology and Biomedicine Technical university of Denmark, Kgs. Lyngby, Denmark

\section{Abstract}

The filamentous fungal genus Stemphylium (Anamophic Pleospora) is often found on various crops, and especially the common animal feed plant Medicago sativa (alfalfa) is often infected by this plant pathogen. With this in mind it is important to consider what consequences such a contamination can have, e.g. production of mycotoxins. (Firsvad et al. (2009))

A clade of Stemphylium spp. i.e. S. herbarum, S. alfalfae, S. sedicola, $S$. tomatonis and S. vesicarium are troublesome to distinguish as they share both morphological and molecular characteristics. This study has focused on using chemotaxonomy via HPLC-UV/VIS-MS analysis as a third method for identification and to investigate the chemical potential of the genus Stemphylium.

A total of 253 unique compounds were used for chemotaxonomy and the majority of these were unknown compounds.

\section{Chemical identification}

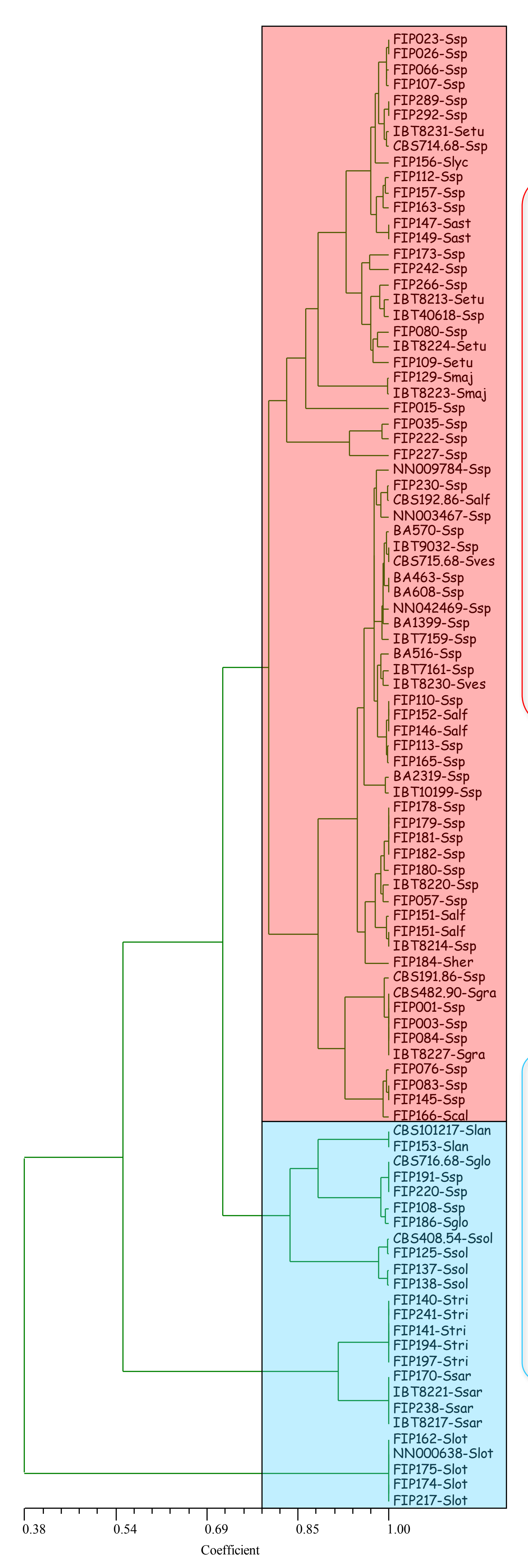

\section{Group C} of group C. Identification via identified. Some were of known isolates e.g. S. gracilariae, $S$. majusculum and $S$. eturmiunum. Interestingly S. lycopersici (group A) within group $\mathrm{C}$.

\section{Group A, B, D, E, F} have solid separation and many unique compounds to differentiate them.

\section{Morphological identification}

The morphology of Stemphylium conidia. Some species require special knowledge of the morphology (I-VI) to identify, while others are easier to identify by this method (VII-IX).

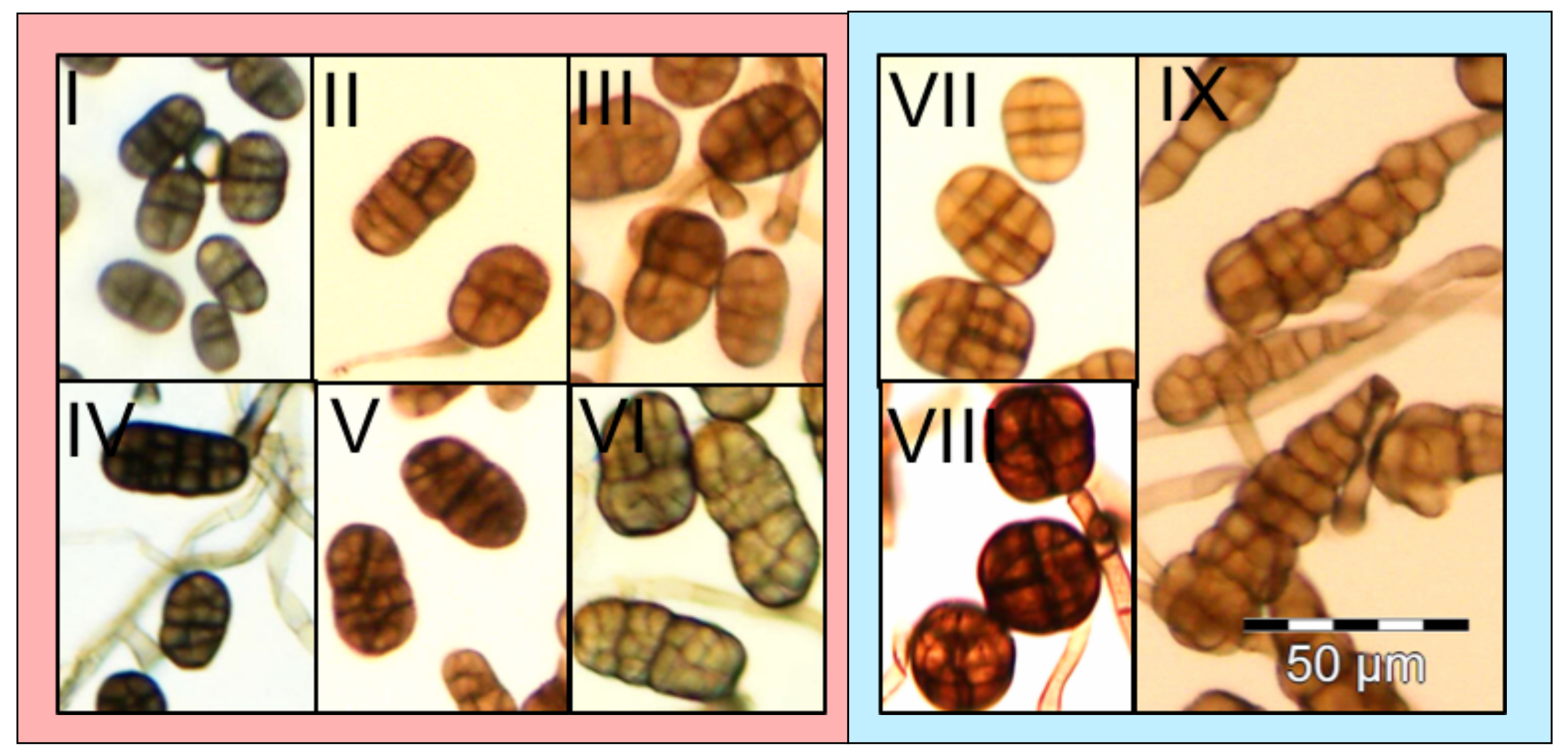

Figure 1. Comparison of micromorphology within the Stemphylium genus. I-S. eturmiunum, II -S. herbarum III - S. astragli, IV - S. gracilareae, V-S. alfalfae, VI - S. majusculum, VII - S. loti, VIII -S. sarciniforme and IX - S. lancipes. Same scale bar for all pictures.

\section{Examples of compounds}

The majority of known Stemphylium compounds are of polyketide origin.

Chemotaxonomy gave some resolution phylogeny would give more resolution but a total of 8 chemical groups were and S. callistephi (group D) clustered

All species of this group are very easy to distinguish from group $\mathrm{C}$. These also

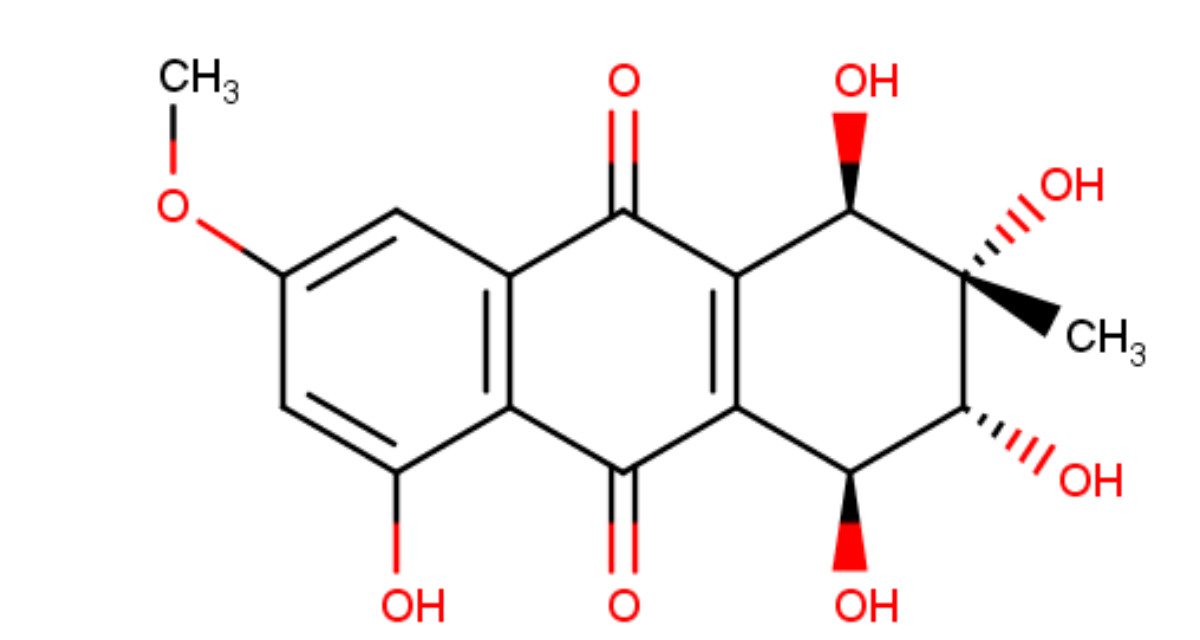

Stemphylin

Stemphylium marker

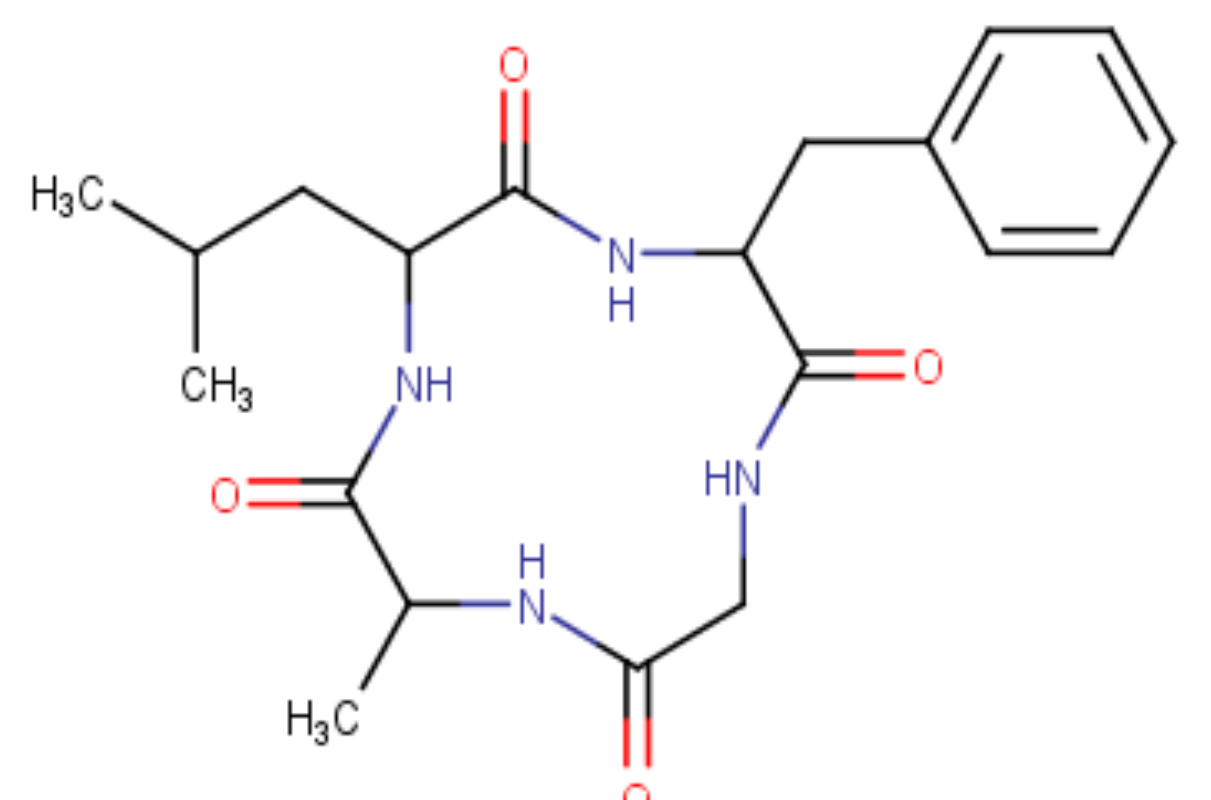

Dihydrotentoxin Group C

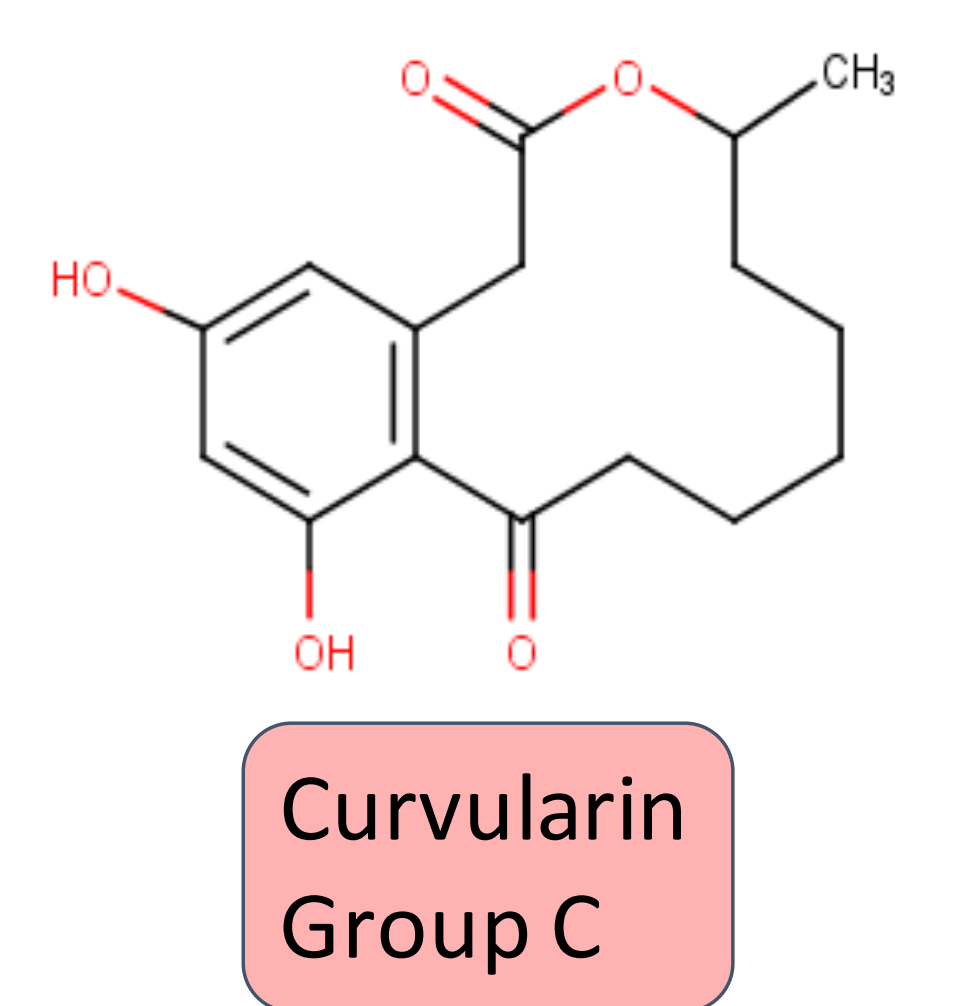

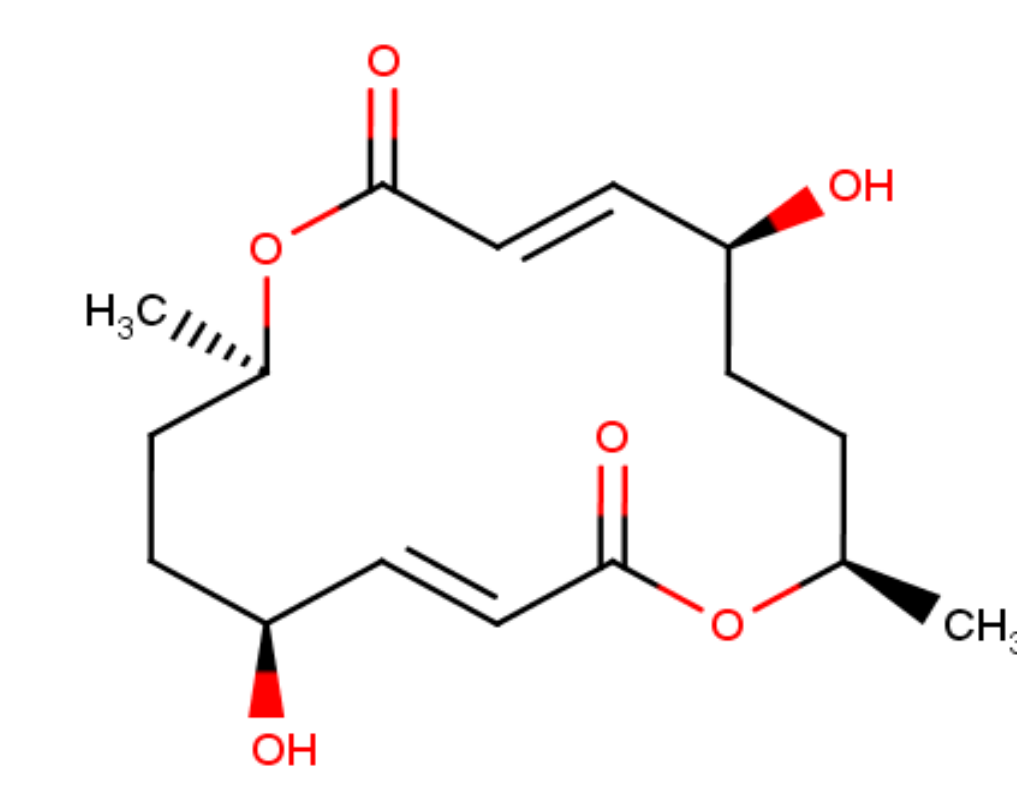

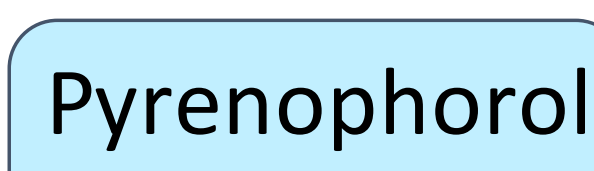
S. loti marker
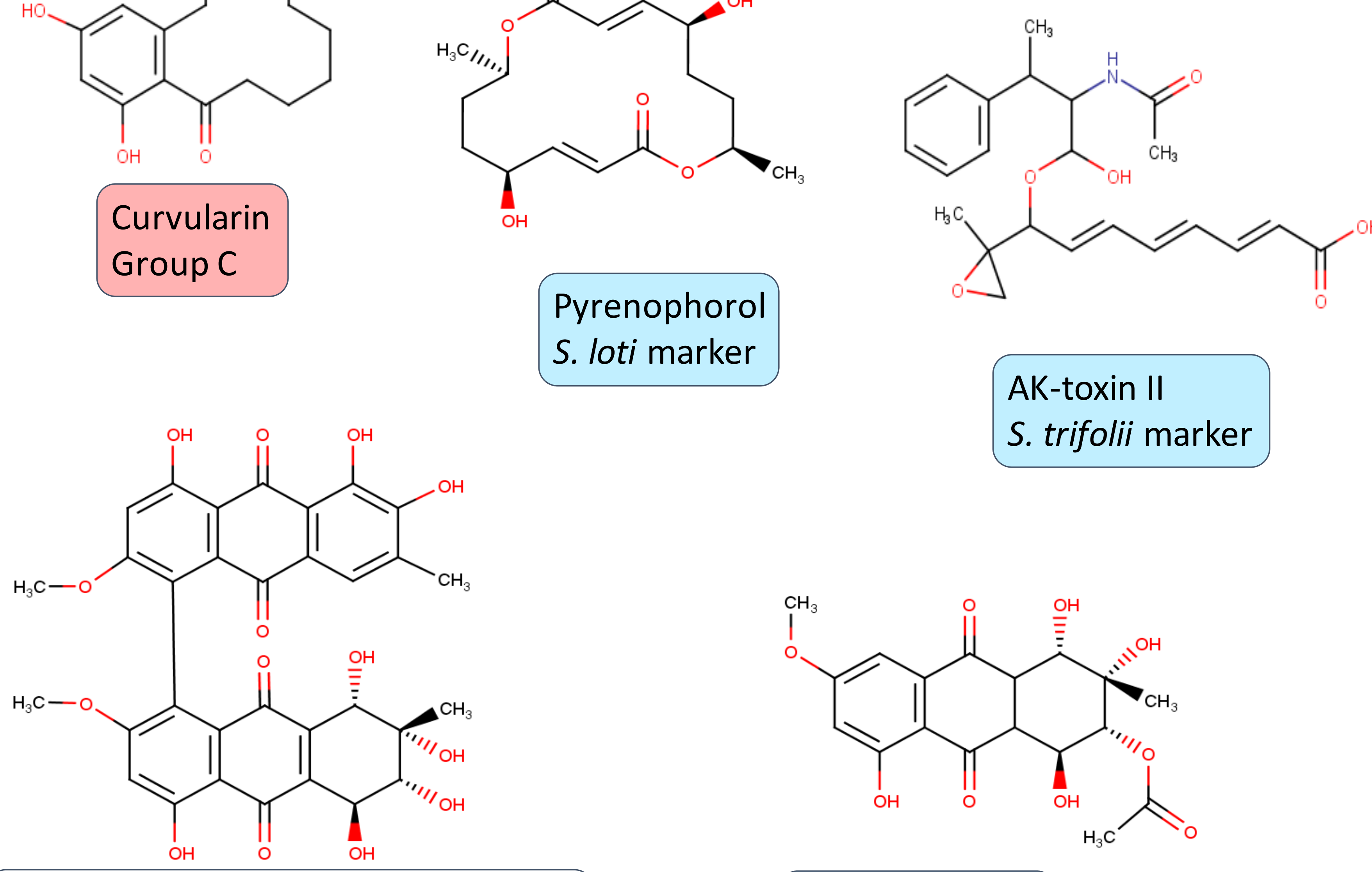

Alterporriol G

Group C, S. solani and S. globuliferum

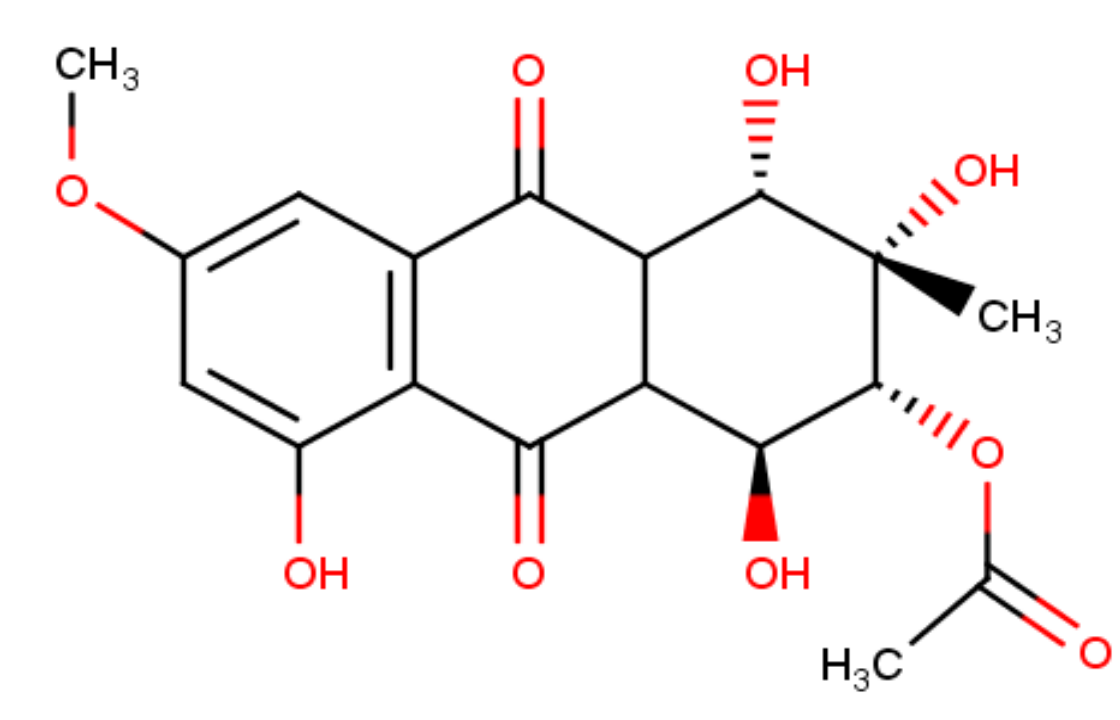

Altersolanol M S. solani marker

\section{Conclusion and perspectives}

Chemotaxonomy with the genus of Stemphylium gave a new tool for identification of the individual species. Also, a list of detected compounds within the genus has been made. With this list it is possible to mine for novel bioactivities as it is possible to analyze vastly different metabolic profiles within the same genus. 